5. Сорина М. О. Цвет и символ в искусстве, дизайне и архитектуре. Москва : МарТ, 2003. 288 с.

6. Frampton K. Modern Architecture. A Critical History. London, T \& H, 1992. 376 p.

7. Iokimov P., Stoilova L. Sezession and Bulgarian Architecture. Lexicon. Time \& beauty. Art Nouveau In The Bulgarian Cities. Collina V. (Ed.), 2014, pp. 18-25.

8. Stoilova L., lokimov P. The Symbolism of Decorations in Art Nouveau Style. Arhitektura. 2014. № 4. pp. 4955. URL : http://20c-arch-bg.blogspot.com/2015/01/six-months-11072014-11012015.html.

\title{
References
}

1. Ivashko, Yu. (2015). Modern of Western Europe, Ukraine and China: ways of transformation and implementation. Kiev: Phoenix [in Russian].

2. Kirikov, B. M. (1987). Petersburg Modern. Notes about architecture and monumental-decorative art. Panorama of the arts, no. 10, pp. 99-148 [in Russian].

3. Koroleva, S. V., Kosheleva, A. A. (2013). A History of Art Nouveau. Features of the artistic imagery of the subject decoration of the interior and decorative arts. News of Tula State University, issue 1, pp. 67-71 [in Russian].

4. Pankalo, S. I. (2016). Principles and acceptance of application of architectural decoration on buildings of Lviv of the end of XIX - beginning of XX century. Modern Problems of Architecture and Urban Development, issue 45, pp. 98-108 [in Ukrainian].

5. Sorina, M. O. (2003). Color and symbol in art, design and architecture. Moscow: March [in Russian].

6. Frampton, K. (1992). Modern Architecture. A Critical History. London, T \& H [in English].

7. lokimov, P., Stoilova, L. (2014). Sezession and Bulgarian Architecture. Lexicon. Time \& beauty. Art Nouveau In The Bulgarian Cities. Collina V. (Ed.), pp. 18-25 [in English].

8. Stoilova, L., lokimov, P. (2014). The Symbolism of Decorations in Art Nouveau Style. Arhitektura. 2014. № 4. pp. 49-55. URL : http://20c-arch-bg.blogspot.com/2015/01/six-months-11072014-11012015.html [in Bulgarian].

Стаття надійшла до редакції 04.11.2019 р. Прийнято до публікації 22.11.2019 р.

УДК 793. $38(4-11) « 18 »$

Павлюк Тетяна Сергіївна

кандидат мистецтвознавства, доцент

Київського національного університету культури і мистецтв

24caratsofart@gmail.com

ORCID 0000-0002-3940-9159

\section{СТАНОВЛЕННЯ ТА ТЕНДЕНЦІЇ РОЗВИТКУ СПОРТИВНОГО БАЛЬНОГО ТАНЦЮ В НІМЕЧЧИНІ}

\begin{abstract}
Мета статті - виявити внесок німецьких танцюристів та вчителів танців у становлення спортивних бальних танців; охарактеризувати специфіку розвитку конкурсного танцювального руху в Німеччині та діяльність танцювальних організацій в XX ст. Методологія дослідження. 3 огляду на багатоаспектність означеної проблематики дослідження має комплексний міждисциплінарний характер. Застосовано загальнонаукові та мистецтвознавчі методи: історичний (для вивчення історичного періоду формування конкурсного бального танцю в Німеччині), аксіологічний (для об'єктивного визначення та аргументації впливу діяльності німецьких танцювальних організацій на становлення конкурсного бального танцю як організованого виду спорту), метод біографічної реконструкції (для детального відтворення фррагментів біографрії провідних німецьких танцюристів і вчителів танцю XX ст.), що дозволило осмислити специфріку розвитку конкурсного танцювального руху в Німеччині та процес становлення спортивних бальних танців в історичні ретроспективі. Наукова новизна. Проаналізовано діяльність німецьких танцюристів та вчителів танців XX ст. у контексті формування та становлення спортивного бального танцю. Виявлено вплив німецьких організацій («Рейхської асоціації сприяння розвитку соціальних танців» та «Міжнародної фредерації аматорського танцю») на становлення конкурсного бального танцю як організованого виду спорту. Висновки. Мистецтвознавче дослідження специфіки розвитку конкурсного бального танцю в Німеччині (1910-1990-ті рр.) виявило внесок німецьких танцюристів у процес кодифікації Міжнародного стилю бальних танців, зародження та становлення ансамблевого способу виконання танцювальних програм - формейшн. Виявлено, що протягом XX ст. представники Німеччини здійснили важливі перетворення в бальному танці, посприявши його поступовому становленні як організованого виду спорту, визначенню норм та концепцій управління на міжнародному рівні.
\end{abstract}

Ключові слова: бальні танці, спортивний бальний танець, німецькі танцювальні організації, танцювальні турніри.

Павлюк Татьяна Сергеевна, кандидат искусствоведения, доцент Киевского национального университета культуры и искусств

Становление и тенденции развития спортивных бальных танцев в Германии

Цель статьи - выявить вклад немецких танцоров и учителей танцев в становление спортивных бальных танцев; охарактеризовать специфику развития конкурсного танцевального движения в Германии и деятельность танцевальных организаций в XX в. Методология исследования. Учитывая многоаспектность указанной пробле-

() Павлюк Т. С., 2020 
матике исследования имеет комплексный междисциплинарный характер. Применены общенаучные и искусствоведческие методы: исторический (для изучения исторического периода формирования конкурсного бального танца в Германии), аксиологический (для объективного определения и аргументации влияния деятельности немецких танцевальных организаций на становление конкурсного бального танца как организованного вида спорта), метод биографической реконструкции (для детального воспроизведения фррагментов биографии ведущих немецких танцоров и учителей танца XX в.), что позволило осмыслить специфику развития конкурсного и танцевального движения в Германии и процесс становления спортивных бальных танцев в исторической ретроспективе. Научная новизна. Проанализирована деятельность немецких танцоров и учителей танцев XX в. в контексте формирования и становления спортивного бального танца. Выявлено влияние немецких организаций («Рейхской ассоциации содействия развитию социальных танцев» и «Международной фредерации любительского танца») на становление конкурсного бального танца как организованного вида спорта. Выводы. Искусствоведческое исследование специфики развития конкурсного бального танца в Германии (1910-1990-е гг.) выявило вклад немецких танцоров в процесс кодификации Международного стиля бальных танцев, зарождения и становления ансамблевого способа выполнения танцевальных программ - формейшн. Выявлено, что в течение XX в. представители Германии осуществили важные преобразования в бальном танце, поспособствовав его постепенному становлению как организованного вида спорта, определению норм и концепций управления на международном уровне.

Ключевые слова: бальные танцы, спортивный бальный танец, немецкие танцевальные организации, танцевальные турниры.

\section{Pavlyuk Tetiana, Candidate of Arts, Associate Kyiv National University culture and arts} Formation and development trends of sports ballroom dancing in Germany

The purpose of the article is to identify the contribution of German dancers and dance teachers to the development of sports ballroom dancing; to characterize the specifics of the development of competitive dance movement in Germany and the activities of dance organizations in the twentieth century. Methodology. Considering the multidimensional nature of the indicated research problems, it has a complex interdisciplinary nature. General scientific and art history methods were applied: historical (to study the historical period of the formation of competitive ballroom dance in Germany), axiological (to objectively determine and argue the influence of the activities of German dance organizations on the formation of competitive ballroom dance as an organized sport), the method of biographical reconstruction (for detailed reproduction fragments of the biography of leading German dancers and dance teachers of the twentieth century), which made it possible to comprehend the specifics of the development of the competition movement and dance movement in Germany and the process of becoming a sports ballroom dance in historical retrospective. Scientific novelty. The activity of German dancers and dance teachers of the twentieth century is analyzed. in the context of the formation and formation of sports ballroom dance. The influence of German organizations (the Reich Association for the Promotion of Social Dance Development and the International Federation of Amateur Dance) on the development of competitive ballroom dance as an organized sport is revealed. Conclusions. An art study of the specifics of the development of competitive ballroom dancing in Germany (1910-1990s) revealed the contribution of German dancers to the codification of the International Style of Ballroom Dancing, the origin and formation of the ensemble method of performing dance programs - formation. It is revealed that during the twentieth century. German representatives made important transformations in ballroom dancing, contributing to its gradual formation as an organized sport, the definition of norms and concepts of management at the international level.

Key words: ballroom dancing, sports ballroom dancing, German dance organizations, dance tournaments.

Актуальність теми дослідження. Загальновизнаним лідером становлення конкурсних бальних танців XX ст., внесок у формування, стандартизацію та еволюціонування десяти танців Європейського стилю беззаперечно є Великобританія. Сформульовані членами Імператорської асоціації вчителів танців перші правила європейського стандарту бальних танців, а головне - система техніки їх виконання, стала основою англійської школи бальної хореографії - однієї з найвідоміших та найшановніших у світі. Не менш важливий внесок у розвиток конкурсної програми спортивних бальних танців здійснили й німецькі танцюристи.

Мета статті - виявити внесок німецьких танцюристів та вчителів танців у розвиток і становлення спортивних бальних танців, а також охарактеризувати ґенезу конкурсного руху в Німеччині XX ст.

Аналіз публікацій засвідчив наявність багатьох наукових праць, присвячених вивченню процесу становлення конкурсного бального танцю в XX ст. Проте зарубіжними та вітчизняними дослідниками (А. Вєтринська, О. Плахотнюк, Ю. Сахневич, Л. Шетопал та ін.) означене питання розглядається переважно крізь призму формування, розвитку та популяризації міжнародного (англійського) стилю бальних танців, діяльності провідних англійських танцюристів, а також специфіки спортивного бального танцю за радянських часів.

Профресійна діяльність німецьких танцюристів, тренерів та хореографів XX ст. у процесі постановки танців, формування конкурсних програм та організації змагань зі спортивних бальних танців, великою мірою лишається поза увагою сучасних науковців, побіжно висвітлюючись в окремих публікаціях (наприклад, Д. Белявський «Генезис формейшн в танцювальному спорті на світовій арені» [1]; О. Бредіхін «Віхи історії спортивних бальних танців та тенденції розвитку танцювальних програм» [2] та ін.) і потребує ґрунтовного мистецтвознавчого дослідження.

Виклад основного матеріалу. Становлення конкурсного бального танцю в Німеччині розпочалося у 1910-х рр. Перший танцювальний турнір у берлінському Адміралспаласті (біля станції Фрідріхштрассе), організований за підтримки Ф.В. Коебнера - німецького журналіста і письменника, 
головного редактора журналу «Елегантний світ», автора книги «Танцювальний бревіарій» («TanzBrevier», 1913 р.), відбувся в 1912 р. Танцювальні пари виконували «Ванстеп», «Бостон» і «Танго». У 1919 р. організовано та проведено перший німецький чемпіонат з бальних танців у Берліні. За рік у Німеччині засновано, а у 1921 р. офріційно зареєстровано, «Рейхську асоціацію танцювального спорту» (Reichsverband für Tanzsport) та організацію-спадкоємицю - «Аматорську асоціацію танцювального спорту» (DTV), першими президентами якої були Б. фон Резнік (1921-1924рр.) та X. фон Споенла (1924-1935рр.). Варто зазначити, що в Англії Національну спілку танцюристів-аматорів було засновано лише через 12-ть років [3, 73].

Важливу роль в процесі розвитку конкурсної програми спортивних бальних танців, а саме створення напряму формейшн, відіграла діяльність вчителя танців Р. Соммера, власника танцювальної школи в Берліні. Д. Белявський, визначаючи роль Англії та Німеччини в процесі зародження та еволюціонування формейшн, стверджує, що саме танцюристи Німеччини є авторами нового, ансамблевого способу виконання танцювальних програм. Науковець зазначає, що одним із основоположників даного танцювального напряму (групового танцювального виступу, заснованого на рухах певного популярного соціального танцю, що характеризується стилевою єдністю костюмів учасників, синхронністю кроків та вивіреністю побудов) $є$ Рейнфорд Соммер, який у 1922 р. першим зібрав та узагальнив досвід ревю й кабаре, збагативши танцювальні композиції інноваційними елементами танцювальних стилів та прийомів, створивши новий танець «Танго-кадриль» для команди танцюристів $[1,66]$. У 1920-1930-х рр. Р. Соммер був відомий у танцювальному світі не лише Німеччини, а й Франції та Англії, неодноразово був членом журі міжнародних змагань. Танцюрист, тренер і хореограф з неабияким ентузіазмом проводив кампанію за новий сучасний стиль, новаторську хореографрічну форму конкурсного бального танцю.

Танець напрямку формейшн, уперше продемонстрований восени 1922 р. у Берлінському зоопарку, в червні 1924 р. було показано під час берлінського тижню спорту в Люстгартені «Berliner Turnund Sportwoche», а згодом у багатьох містах Імперії, публіка сприймала з неабияким ентузіазмом. Утім, як свідчить Х.-Д. Шефер, посилаючись на висловлювання автора танцю Р. Соммера, його занадто консервативні колеги виступали проти таких новацій: «є ворожо налаштовані люди, які бачать у сучасному танці символ зіпсованого часу і знищують його (...) проте танго-кадриль займає своє місце, утворюючи міст зі старого часу до нового (...) шануй старе, вимагай нового, ось наша мета» [7]. «Танго-кадриль» - складний синтез старих і нових форм. Особливо привертала увагу зірка, яку утворювали вісім танцюристів. На думку Х.-Д. Шефера, рік створення танцювальної постановки «Тангокадриль» доцільно вважати роком народження фрормейшн.

у 1932 р. новим танцем формейшн Р. Сомера став «Формейшн-Повільний Фокстрот» («Formations-Slow-Fox») - повільний фокстрот з елегантним капріччіо, який вперше продемонстрували берлінські танцювальні пари на балу «Золоті листя» в берлінському готелі «Еспланаде» [3, 74].

Неабияку роль у процесі становлення та розвитку формейшн у 1930-х рр. відіграла творча діяльність К. Рібелінга, вчителя танців із Каселя, який досліджував історичні танці та здійснював постановки показових виступів нового танцювального напрямку. 31949 р. за ініціативи К. Рібелінга в німецьких танцювальних чемпіонатах на показових виступах виступали танцювальні колективи (вперше у м. Касель), а за рік, у місцевому отелі м. Вестерланда, відбувся перший формейшн турнір за участю німецьких та датських команд $[1,66]$.

Інтегрували танець формейшн у програму фестивалю бального танцю англійці: з 1932 р. виступала танцювальна команда О. Ріпман, а перші змагання з формейшн відбулися в Блекпулі в 1937 р. Перемогу здобули датські танцюристи, що свідчить про популярність формейшн в західноєвропейських країнах. Проте, як стверджує Х.-Д. Шефрер, в Англії для турнірів не вистачало певних умов, оскільки танець фоормейшн визначався перш за все профресійністю хореографії [7]. У програму Відкритого чемпіонату Великобританії змагання серед команд формейшн (програма «Стандарт») були включені лише у 1957 р.

Не дивлячись на неабияку популярність з боку глядачів та багатьох танцюристів й хореографів, в Німеччині формейшн отримав офріційне визнання лише у 1962 р., сприймаючись протягом сорока років лише візуально естетичною варіацією спортивних танців, яку традиційно виконують на концертах та під час показових виступів.

Розвиток організаційної системи конкурсного бального танцю в Німеччині відбувався паралельно з формуванням навчально-методичної бази - протягом 1922-1923 рр. була заснована «Німецька асоціація вчителів танців» («Allgemeine Deutsche Tanzlehrer-Verband», ADTV); «Рейхською асоціацію танцювального спорту» прийнято та опубліковано «Загальні правила турніру»; Х. Поллак видає монографію «Революція бальних танців» (1922р.). У 1924 р. спеціалізованим друкованим органом асоціації став журнал «Танцюрист» («Der Tänzer», головний редактор А. Флек). 1 лютого 1925 р. було засновано «Рейхську асоціацію сприяння розвитку соціальних танців» («Reichsverband zur Pflege des Gesellschaftstanzes"), членами президії якої стали члени «Рейхської асоціації танцювального спорту». Під керівництвом організацій у 1927 р. у Франкфурті організовано та проведено перший європейський чемпіонат серед танцюристів-аматорів. 
Важливе значення для розвитку професійної та міждисциплінарної підготовки вчителів танців Німеччини, в період становлення системи конкурсного бального танцю, відіграли конференції, перша 3 яких відбулася у 1928 р. в Бад-Кіссінгегі. Зауважимо, що дана традиція триває й донині - визнаючи важливість створення професійного представництва тренерів, у 1988 р. було створено «Асоціацію тренерів танцювального спорту в Федеративній Республіці Німеччина» («Tanzsporttrainerlnnen in Deutschland»), що є організацією-членом «Німецької асоціації танцювального спорту» та організовує проведення літнього конгресу в Бад-Кіссінгегі. Дана ініціатива сприяє співробітництву та обміну інформацією зі спортивними організаціями, професійними асоціаціями на регіональному, національному та міжнародному рівнях [8].

У 1932 р. «Рейхською асоціацією бальних танців» для навчання та виконання під час танцювальних турнірів допускаються «Віденський вальс» та «Румба» (вперше на чемпіонаті Німеччини, 1932 р.), що значно збагатило традиційну програму змагань.

Варто зауважити, що у 1932 р. у Бремені було засновано клуб «Green-Gold», який протягом 1964-1984 рр., під керівництвом Г. Майнера, здобув статус найвідомішого німецького клубу спортивних бальних танців [3, 74].

У контексті розвитку та популяризації «Танго», варто згадати діяльність німецького танцюриста аматора Ф. Кемпа, який у 1933 р. переїхав до Лондона, де експериментував з постановками танцю. У 1935 р. у бальному залі «Асторія» (Лондон, Вест-Енд) Ф. Кемп разом зі своєю англійською партнеркою продемонстрували нову інтерпретацію «Танго» (у спортивному «німецькому стилі»), яка здобула популярність серед танцюристів та вчителів танців, не зважаючи на зацікавленість окремих членів танцювальних товариств експериментуванням з протилежним стилем - «Танго-фрокстротом». Під впливом Ф. Кемпа «Танго» набуває елементів, характерних для сучасного бального танго (гостре стаккато, перебільшені рухи та ін.). Дані модифікації були враховані в нових програмах зі створення єдиного, кодифікованого набору кроків «Танго», виданих Імперським товариством вчителів танцю (створена у 1920 р. програма «Танго» засновувалася на довоєнному французькому варіанті). Окремі теоретики і практики конкурсного бального танцю стверджують, що дану версію «Танго» варто називати «німецьким танго», хоча, як стверджує К. Денністон, Ф. Кемп заперечував, що його версія «мала будь-які німецькі характеристики як такі», позиціонуючи її лише як власну інтерпретацію [4, р. 88].

У вересні 1935 р., за ініціативи членів «Рейхської асоціації сприяння розвитку соціальних танців» та за участю представників танцювальних організацій дев'яти європейських країн, у Празі було засновано першу міжнародну аматорську асоціацію спортивного бального танцю «Міжнародна фредерація аматорського танцю» (Fédération Internationale de Danse pour Amateurs), яку очолив Ф. Бюхлер із Граца. Вже за рік (у 1936 р.) федерація організувала та провела в німецькому місті Бад Нойхейм перший міжконтинентальний чемпіонат світу серед аматорів, участь в якому брали танцюристи 3 п'ятнадцяти країн трьох континентів.

Після закінчення Другої світової війни діяльність організаційної системи конкурсного спортивного танцю в Німеччині було відновлено. У 1946 р. в Кельн-Юнкерсдорфі за ініціативи К. Мейєра та Г. Больца засновано «Асоціацію німецьких клубів бальних танців» («Interessengemeinschaft Deutscher Clubs zur Pflege des Gesellschaftstanzes», 31948 p. - «Deutscher Verband zur Pflege des Gesellschaftstanzes»), а за кілька років - «Об'єднання німецьких асоціацій вчителів танців» (Arbeitsgemeinschaft deutscher Tanzlehrer-Verbände) та «Бюро аматорських турнірів Німеччини» (Deutsches Amateur-Turnieramt); відновила діяльність «Німецька асоціація вчителів танців» (з 1950 р.).

Членами Бостонського клубу в Дюсельдорфі в 1949 р. організовано перший великий танцювальний турнір повоєнного періоду, а у Мюнхені та Гармиш-Партенкірхені - Кубок Європи та Альпійський Кубок відповідно.

Двадцятирічна діяльність «Міжнародної фредерації аматорського танцю», що співпала 3 періодом Другої світової війни та ворожнечею між професійними та аматорськими організаціями припинилася у 1956 р. Утім, за ініціативи представників Німеччини, невдовзі переформатувалася в нове офріційне товариство - 12 травня 1957 р. у Вісбадені, в будинку відомого німецького чемпіона з танців О. Тейпеля, представники восьми європейських країн заснували «Міжнародну раду танцюристів аматорів» (International Council of Amateur Dancers), обравши О. Тейпеля президентом (1957-1962 pp.). Варто зауважити, що однією з важливих проблем, що постала перед організацією була необхідність налагодження співпраці з організаціями професійних танцюристів. Це було досягнуто лише у 1965 р. новим президентом Ради Д. Хегеманном - документ, відомий як «Бременська угода» підписано 3 «Міжнародною радою бальних танців» (президент А. Мур) 3 жовтня. «Міжнародна аматорська асоціація» зобов'язувалася організовувати та контролювати проведення міжнародних чемпіонатів для аматорів, а також розроблено умови співпраці (наприклад, суддям «Міжнародної асоціації аматорського танцю» дозволялося брати участь в міжнародних змаганнях) [6].

У 1984 р. за сприянням відомого вчителя спортивних бальних танців Г. Кернера та президента клубу танців у Маннхаймі А. Буттвайлера, президента державної асоціації бальних танців землі Баден-Вюртенберг (Baden-Württembergischen Tanzsportverbandes) В. Дж. Брауна та асоціації спортивних танців Німеччини було організовано турнір «Відкритий чемпіонат Німеччини» (German Open Championship). Відкриття чемпіонату, новаторською концепцією якого передбачалося поєднання в 
межах одного турніру професійних та аматорських танцювальних пар усіх вікових категорій, відбулося у вересні 1987 р. у манхеймському готелі «Розенгартен». Понад 600 пар протягом трьох днів брали участь у 12-ти конкурсних програмах зі стандарту та латиноамериканських танців. 3 масштабною популяризацією спортивних бальних танців наприкінці XX - на початку XXI ст. (станом на 1997 р. кількість танцювальних пар учасниць перевищувала 2000, а у 2001 р. становила 2632 пари з 49-ти країн п'яти континентів) відповідних змін зазнала й стандартна програма турніру: з 1997 р. чемпіонат триває п'ять днів, а у 2003 р. - шість; з'явилися нові вікові групи для юніорів (підлітки, юніори I + II та молодь); з метою розширення спектру танцювального спорту в програму чемпіонату було включено Кубок Світу з Рок-н-ролу, Чемпіонат Світу з Латини, Кубок Світу з Аргентинського танго (з 2001 р.), Чемпіонат Європи з Хіп-Хопу (2003 р.), турнір Rising Star (з 2005 р.), Чемпіонат світу з Бугі-Вугі (з 2008 р.), а також інші номінації та премії (з 2006 р. - 36 змагань); з 2004 р. Відкритий чемпіонат Німеччини проводиться у Штутгарті (концертний зал і конференц-центр «Kultur- und Kongresszentrum Liederhalle») [5].

Наразі German Open Championship - найбільший в світі фестиваль танцювального спорту, не менш популярний за Блекпульський (Англія) й вважається одним із головних подій у світі спортивних бальних танців.

Під головуванням Д. Хегеманна (1965-1998 рр.) «Міжнародна рада танцюристів аматорів», до якої приєдналися багато національних аматорських організацій, стала частиною світового руху бальних танців. Позиціонуючи танець як спорт, змінила у 1990 р. назву на «Міжнародну федерацію танцювального спорту» (International DanceSport Federation), стала членом «Загальної асоціації міжнародних спортивних федерацій» (General Association of International Sports Federations) та «Міжнародної всесвітньої асоціації ігор» (International World Games Association) у 1995 р. [6].

Наукова новизна. Проаналізовано діяльність німецьких танцюристів та вчителів танців XX ст. у контексті формування та становлення спортивного бального танцю. Виявлено вплив німецьких організацій («Рейхської асоціації сприяння розвитку соціальних танців» та «Міжнародної фредерації аматорського танцю») на становлення конкурсного бального танцю як організованого виду спорту.

Висновки. Мистецтвознавче дослідження специфіки розвитку конкурсного бального танцю в Німеччині (1910-1990-ті рр.) виявило внесок німецьких танцюристів у процес кодифікації Міжнародного стилю бальних танців, зародження та становлення ансамблевого способу виконання танцювальних програм - формейшн. Виявлено, що протягом XX ст. представники Німеччини здійснили важливі перетворення в бальному танці, посприявши його поступовому становленні як організованого виду спорту, визначенню норм та концепцій управління на міжнародному рівні.

\section{תimepamypa}

1. Белявский Д. Н. Генезис формейшн в танцевальном спорте на мировой арене. Roczniki Naukowe Wyższej Szkoły Wychowania Fizycznego i Turystyki w Białymstoku ; komitet wydawniczy : D. Sokołowska (redaktor naczelna). 2017. № 2 (20). Białystok : WSWFiT, 2017. pp. 65-76.

2. Бредихин А. Ю. Вехи истории спортивных бальных танцев и тенденции развития танцевальных программ. Знание. Понимание. Умение: научный журнал. 2012. № 3. С. 322-325.

3. Burgauner Ch. 75 Jahre Deutscher Tanzsportverband Zwischenbilanz auf dem Weg ins 21. Jahrhundert. Tanzspiegel. 2006. № 6. pp. 71-90.

4. Denniston Ch. The Meaning of Tango: The Story of the Argentinian Dance. London: Portico, 2007. 224 p.

5. Estler H. The history of the German Open Championships. 2011. URL : http://www.gocstuttgart.ru/ (дата звернення 10.06.2019).

6. How it all started. World dance sport federation. URL https://www.worlddancesport.org/WDSF/History/How_It_All_Started (дата звернення 12.06.2019).

7. Schäfer H.-J. Die Geschichte des Formationstanzens. URL : http://docplayer.org/28698581-Diegeschichte-des-formationstanzens.html (дата звернення 11.06.2019).

8. Tanzsporttrainerlnnen in Deutschland. URL : http://www.tstvev.de/wir-ueber-uns/(дата звернення 12.06.2019).

\section{References}

1. Belyavsky, D. N. (2017). Genesis formation in dance sport on the world stage. Roczniki Naukowe Wyższej Szkoły Wychowania Fizycznego i Turystyki w Białymstoku; komitet wydawniczy: D. Sokołowska (redaktor naczelna), no. 2 (20), pp. 65-76 [in Russian].

2. Bredikhin, A. Yu. (2012). Milestones in the history of sports ballroom dancing and trends in the development of dance programs. Knowledge. Understanding. Skill: scientific journal, no. 3, pp. 322-325 [in Russian].

3. Burgauner, Ch. (2006). 75 Jahre Deutscher Tanzsportverband Zwischenbilanz auf dem Weg ins 21. Jahrhundert. Tanzspiegel, no. № 6, pp. 71-90 [in English].

English].

4. Denniston, Ch. (2007). The Meaning of Tango: The Story of the Argentinian Dance. London: Portico [in

5. Estler, H. (2011). The history of the German Open Championships. Available at : http://www.gocstuttgart.ru/ [in English]. 
6. How it all started. World dance sport federation. Available at : https://www.worlddancesport.org/WDSF/History/How_It_All_Started [in English].

7. Schäfer, H.-J. Die Geschichte des Formationstanzens. Available at : http://docplayer.org/28698581-Diegeschichte-des-formationstanzens.html [in English].

8. TanzsporttrainerInnen in Deutschland. Available at : http://www.tstvev.de/wir-ueber-uns/ [in English].

Стаття надійшла до редакції 08.10.2019 p. Прийнято до публікації 31.10.2019 р.

УДК 792.82:7.072.3(477)

\author{
Підлипська Аліна Миколаївна \\ кандидат мистецтвознавства, професор, \\ професор кафедри хореографрічного мистецтва \\ Київського національного університету \\ культури і мистецтв \\ ORCID 0000-0002-7892-337X \\ alinaknukim@ukr.net
}

\title{
РЕПЕРТУАР БАЛЕТНОГО ТЕАТРУ РАДЯНСЬКОЇ УКРАЇНИ ДРУГОЇ ПОЛОВИНИ 20-Х РОКІВ ХХ СТОЛІТТЯ У СВІТЛІ КРИТИКИ
}

\begin{abstract}
Мета дослідження - проаналізувати репертуар балетного театру Радянської України другої половини 20x pp. XX ст. крізь призму тогочасного критичного дискурсу. Методологія. Застосування методів аналізу джерел, концепцій, порівняння критично-оцінних підходів до балетного репертуару забезпечили об'єктивне проведення дослідження. Наукова новизна. Вперше проаналізовано репертуар балетного театру Радянської України другої половини 20-х рр. XX ст. крізь призму естетичних концепцій тогочасної критики. Висновки. 3 налагодженням функціонування Одеського, Київського, Харківського оперно-балетних театрів від середини 20-х рр. XX ст. активізувалася балетна критики. В критичному дискурсі сформувався оцінний критерій відповідно до двох підходів до балетної спадщини: один - періодичне звернення, незначне редагування, збереження традицій; другий - тотальне перероблення всього, що пов'язано з балетом минулого. Переважна частина балетних критиків звертала увагу на наявність чи відсутність зв'язку з балетом минулого навіть в оригінальних виставах, що було проявом панування окремих рис пролеткульту. Серед балетних вистав, що стали об'єктом уваги критиків, виділяють «Лебедине озеро», «Дон Кіхот» (з мінімальними редакціями, максимальним збереженням тексту класичної вистави початку XX ст.), «Корсар» (значне перероблення, порівняно з класичним першоджерелом), «Йосип Прекрасний» та «Гротеск» (новаторські балетні вистави, перенесені з московського майданчика, мінімально адаптовані до умов одеського та харківського театрів), «Червоний мак» (значний ступінь оригінальності), «Казка про блазня, що сімох блазнів перемудрив» (перше оригінальне втілення). В умовах широкої тематичної та лексичної палітри балетів в Радянській Україні другої половини 20-х рр. XX ст. відбулося становлення українського балетного критичного дискурсу, що враховував радянські політико-ідеологічні настанови.
\end{abstract}

Ключові слова: український балетний театр, критика балету, художня критика, репертуар, балет.

Пидлыпская Алина Николаевна, кандидат искусствоведения, профрессор, профрессор кафедры хореографрического искусства Киевского национального университета культуры и искусств

Репертуар балетного театра Советской Украины второй половины 20-х годов XX века в свете кри-

тики

Цель исследования - проанализировать репертуар балетного театра Советской Украины второй половины 20-х гг. XX в. сквозь призму тогдашнего критического дискурса. Методология. Применение методов анализа источников, концепций, сравнение критических оценочных подходов к балетному репертуару обеспечили объективное проведение исследования. Научная новизна. Впервые проведена дифференциация репертуара балетного театра Советской Украины второй половины 20-х гг. XX в. сквозь призму эстетических концепций тогдашней критики. Выводы. С налаживанием функционирования Одесского, Киевского, Харьковского опернобалетных театров с середины 20-х гг. XX в. активизировалась балетная критики. В критическом дискурсе сформировался оценочный критерий в соответствии с двумя подходами к балетному наследию: один - периодическое обращение, малое изменение, сохранение традиций; второй - тотальная переработка всего, что связано с балетом прошлого. Большинство балетных критиков обращало внимание на наличие или отсутствие связи с балетом прошлого даже в оригинальных спектаклях, что было проявлением господства отдельных черт пролеткульта. Среди балетных спектаклей, ставших объектом внимания критиков, выделяют «Лебединое озеро», «Дон Кихот» (с минимальными редакциями, максимальным сохранением текста классического спектакля начала XX в.), «Корсар» (значительная переработка по сравнению с классическим первоисточником), «Иосиф Прекрасный» и «Гротеск» (новаторские балетные спектакли, перенесенные с московской сцены, минимально адаптированные к условиям одесского и харьковского театров), «Красный мак» (значительная степень оригинальности), «Сказка про шута, семерых шутов перешутившего» (первое оригинальное воплощение). В условиях широкой тематической и лексической палитры балетов в Советской Украине второй половины 20-х гг. XX в. произошло становление украинской балетного критического дискурса с учетом советских политико-идеологических установок.

Ключевые слова: украинский балетный театр, критика балета, художественная критика, репертуар, балет.

() Підлипська А. М., 2020 